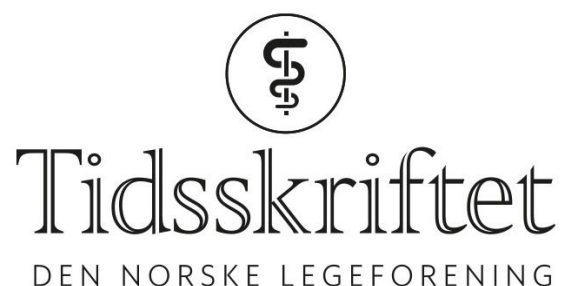

DEN NORSKE LEGEFORENING

\title{
Hvor er helsepersonell i rusdebatten?
}

DEBATT

\section{JOHN MELHUS}

E-post: john.melhus@rusreform.no

John Melhus er leder for Foreningen Tryggere Ruspolitikk i Trøndelag og tidligere rusbruker. Forfatter har fylt ut ICMJE-skjemaet og oppgir ingen interessekonflikter.

Vi trenger fagfolk i diskusjonen om forbudspolitikkens helseskadelige virkninger.

Både tidsskriftet BMJ og The Johns Hopkins-Lancet Commission on Drug Policy and Health går inn for ny reguleringsmodell for illegale rusmidler av hensyn til folks helse $(1,2)$. Begge oppfordrer leger til å engasjere seg i saken. Mindre oppmerksomhet har blitt viet forbudspolitikkens konsekvenser for psykisk helse. Som bruker av rusmidler i over 35 år $\emptyset$ nsker jeg å dele mine erfaringer med norske leger.

Både angsten for å bli pågrepet, traumene av å bli arrestert eller slengt i bakken i en plutselig razzia kan gi varige mén. Sammen med kjente bakenforliggende årsaker hos dem som virkelig sliter, som traumer, vold, overgrep og psykiske lidelser, kan forbudet i seg selv skape en overveldende psykisk belastning for mange. Jeg lurer på om ikke kriminalisering og forfølgelse i seg selv kan medvirke til psykiske problemer for brukere, uavhengig av om de har problematisk rusmiddelbruk eller ikke?

Når jeg sammenligner den restriktive norske forbudspolitikken og den avkriminaliserte nederlandske politikken, hvor brukere ikke forfølges (3), er det noen forhold som slår meg: Å slippe å bli ransaket eller forfulgt av politi skaper mindre redsel og angst, i tillegg til at man føler seg mindre «utenfor» og annerledes. Min erfaring er at man i Nederland kan holde et ganske høyt daglig forbruk stabilt i flere år uten å måtte ty til kriminalitet. Prisen på rusmidlene er lavere enn i Norge, kvaliteten mer stabil og miljøet blant brukerne mindre preget av vold og angst.

\section{Helsepersonell etterlyses i rusdebatten}

Dette har fått meg til å spørre: Hvorfor har det vært så lite oppmerksomhet blant fagpersoner innen medisin, psykiatri og psykologi rundt effekten forbudet har på den psykiske helsen til de som sliter med rusmidler? Jeg lurer på om noe av grunnen kan være at frykten for å snakke om dette innad i helsevesenet er stor, at det å kritisere dagens forbudspolitikk kan få negative konsekvenser? Min erfaring etter samtale med enkelte leger og psykiatere viser at dette har vært tilfelle. Flere frykter at både stilling og rykte settes i fare.

Kanskje er det akkurat her vi har mest å lære av Nederland: Fordi bruk av illegale rusmidler ikke er forbudt, kan alle snakke åpent, uten frykt for represalier eller fordømmelse. Det er positivt at både Tidsskriftet (4) og Psykologtidsskriftet (5) har viet oppmerksomhet til norsk ruspolitikk de to siste årene. Avkriminalisering av brukeren er én ting, kanskje kan vi også 
se på muligheten for å regulere rusmidlene, slik som BMJ og Lancet-kommisjonen tar til orde for $(1,2)$ ? Vi trenger helsearbeidernes stemme i debatten om fremtidens ruspolitikk.

\section{LITTERATUR:}

1. Godlee F. Drugs should be legalised, regulated, and taxed. BMJ 2018;361: k2057. [CrossRef]

2. Csete J, Kamarulzaman A, Kazatchkine M et al. Public health and international drug policy. Lancet 2016; 387: 1427 - 8o. [PubMed][CrossRef]

3. van Laar M, Cruts G, van Ooyen-Houben M et al. The Netherlands Drug Situation 2012. Draft version 28-12-2012. Lisbon: European Monitoring Centre for Drugs and Drug Addiction, 2012: 118.

http://www.emcdda.europa.eu/attachements.cfm/att_213776_EN_2012\%20Netherlands\%20National\%2 oreport\%2ofull.pdf(6.11.2018).

4. Slagstad K. Stoff, straff og sosial smitte. Tidsskr Nor Legeforen 2016;136:1871. [PubMed][CrossRef]

5. Helmikstøl Ø. Ikke sett rusavhengige i bur. Tidsskr Nor Psykol foren 2016; 53: 984 - 5 .

Publisert: 16. november 2018. Tidsskr Nor Legeforen. DOI: 10.4045/tidsskr.18.0822

Mottatt 22.10.2018, første revisjon innsendt 1.11.2018, godkjent 6.11.2018.

(C) Tidsskrift for Den norske legeforening 2020. Lastet ned fra tidsskriftet.no 